\title{
Improvement of Glaze Hardness in Commercial Bone China
}

\author{
Hyeong-Jun Kim ${ }^{\dagger}$, Yoon Soo Han, Dong-Hwan Kim, Da-Mi Kim, Jae-Ho Choi, \\ Sung-Min Lee, Yoojin Kim, and Hyung-Tae Kim \\ Korea Institute of Ceramics Engineering \& Technology, Icheon 17303, Korea \\ (Received September 10, 2015; Revised October 1, 2015; Accepted October 2, 2015)
}

\begin{abstract}
In order to improve the hardness of commercial bone china, we attempted to control the glost firing temperature and apply a chemical strengthening process. When the glost firing time was longer or its temperature was higher than normal conditions, the hardness was improved by approximately $5 \%$. The chemical strengthening process also enhanced the hardness of the glaze by more than $13 \%$ compared with bone china. It is believed that the enhancement of the hardness of the glaze was related to the development of residual compressive stress in the glaze due to 1) the increase in the calcium phosphate phase in the interface layer between the body and the glaze after firing, and 2) the increase of the $\mathrm{K}^{+}$concentration on the glaze surface during the chemical strengthening process.
\end{abstract}

Key words : Bone china, Glaze, Residual stress, Chemical strengthening, Hardness

\section{Introduction}

$\mathrm{S}$ ince the development by Thomas Frye of United Kingdom in 1749 , bone china kept being developed to currently enjoy the position of a the highest-class living pottery. ${ }^{1)}$ Domestically, the production of bone china began in 1970's, and no difference in the current quality level from advanced products can be seen. Recent bone china products show a strength higher than about $100 \mathrm{MPa}$ and a fracture toughness on the level of about $2 \mathrm{MPam}^{1 / 2}$, demonstrating that mechanical characteristics are excellent in comparison with other tablewares. ${ }^{2)}$ Since 2000's, efforts to increase the strength of bone china have been attempted through improving raw materials, such as controlling the silica particle size of china body itself ${ }^{3-5)}$ or changing compositions of the glaze. ${ }^{6-8)}$

Glaze for bone china began with $\mathrm{SiO}_{2}-\mathrm{PbO}-\mathrm{K}_{2} \mathrm{O}$ system having a $\mathrm{PbO}$ content of more than $40 \mathrm{wt} \%$, which is being suppressed recently in the glaze for china due to the environment and safety problems. ${ }^{1)}$ So, a variety of lead-free frit glazes were filed for patents and commercialized also. $\mathrm{B}_{2} \mathrm{O}_{3}$ $\mathrm{SiO}_{2}$ system, called ABS(Advanced Borosilicate), BismuthSilicate system, in which $\mathrm{PbO}$ substituted by bismuth oxide, Zinc-Strontium system and so on belong to the lead-free frit glazes. ${ }^{911)}$ Though ABS glaze is known to have a lower refractive index and less glossy than lead system or bismuth system, it is widely used because it is less costly than other glazes. $^{12)}$

\footnotetext{
${ }^{\dagger}$ Corresponding author : Hyeong-Jun Kim

E-mail : goldbud@kicet.re.kr

Tel : +82-31-645-1446 Fax : +82-31-645-1491
}

Recently, chemical strengthening technique, which is applied to the glass cover for smart phones, was attempted to ceramic dental crown to improve its hardness of glaze layer. ${ }^{13-14)}$ This technique also improved the strength of pottery coated high-fired glaze in the recent study. ${ }^{15}$

As described earlier, although bone china products have recently achieved much improvement in strength and toughness, demand is also continued for improvement in hardness of the glass surface to reduce scratches by such tools as fork or knife. So, in the this study, as received state of ABS glaze in bone china were checked first, and changes in hardness of the glaze layer were observed when controlling the glaze firing conditions or applying the chemical strengthening process.

\section{Experimental Procedure}

Specimens were the bone china products made by H-company with the firing temperature of $1150^{\circ} \mathrm{C}$ and holding time of 30 minutes (denoted as "as-received" in the figures and the tables, and so on, herein). Tables 1 and 2 show the compositions and thermal properties of the body and the glaze obtained through ICP analysis and dilatometry. Since lead-free glaze for bone china is made into a glass powder(frit) by vitrification and pulverization unlike other general glazes, vitreous layer can be easily formed when heattreated above the softening point. However, because the frit glaze consists only of vitreous material lacking in plasticity and adhesion, a small amount of inorganic binder is mixed for use to supplement it. For the inorganic binders, the clay such as bentonite is representative, and New Zealand kaolin was used in this study. ${ }^{16)}$ As-received samples were heated to $1150,1200,1250^{\circ} \mathrm{C}$, respectively, at rising rate of 
Table 1. Compositions of Body and Glaze of Bone China (wt\%)

\begin{tabular}{ccccccccccccc}
\hline & $\mathrm{SiO}_{2}$ & $\mathrm{Na}_{2} \mathrm{O}$ & $\mathrm{B}_{2} \mathrm{O}_{3}$ & $\mathrm{Li}_{2} \mathrm{O}$ & $\mathrm{CaO}$ & $\mathrm{Al}_{2} \mathrm{O}_{3}$ & $\mathrm{ZnO}$ & $\mathrm{K}_{2} \mathrm{O}$ & $\mathrm{ZrO}_{2}$ & $\mathrm{MgO}_{2}$ & $\mathrm{P}_{2} \mathrm{O}_{5}$ \\
\hline Body & 27.3 & 0.47 & - & 0.12 & 30.7 & 12.7 & 0.02 & 0.78 & 0.01 & 0.51 & 25.1 \\
Glaze & 57.5 & 6.88 & 6.2 & 1.63 & 8.05 & 11.8 & 3.02 & 2.99 & 1.63 & 0.08 & - \\
\hline
\end{tabular}

Table 2. Properties of Body and Glaze of Bone China

\begin{tabular}{ccccc}
\hline Sample & $\begin{array}{c}\mathrm{CTE}^{*}\left(50-500^{\circ} \mathrm{C}\right) \\
\left(\times 10^{-6} /{ }^{\circ} \mathrm{C}\right)\end{array}$ & $\begin{array}{c}\mathrm{Tg} \\
\left({ }^{\circ} \mathrm{C}\right)\end{array}$ & $\begin{array}{c}\text { Young's modulus } \\
(\mathrm{GPa})\end{array}$ & $\begin{array}{c}\text { Stress optic coefficient } \\
\left(\mathrm{nm} / \mathrm{cm}^{\prime} /\left(\mathrm{kgf} / \mathrm{cm}^{2}\right)\right.\end{array}$ \\
\hline Body & 8.73 & - & 80 & - \\
Frit & $8.43 \times 10^{-6} /{ }^{\circ} \mathrm{C}$ & 526.6 & - & - \\
Glaze (Frit : kaolin $=10: 1)$ & $8.41 \times 10^{-6} /{ }^{\circ} \mathrm{C}$ & 545.3 & 79 & 3.798 \\
\hline
\end{tabular}

${ }^{*}$ CTE : Coefficient of Thermal Expansion

$10^{\circ} \mathrm{C} / \mathrm{min}$. and additionally fired for 30 minutes followed by furnace cooling. In order to identify the effects of chemical strengthening in bone china, as-received and refired samples were subjected to be immersed in a molten bath of $100 \% \mathrm{KNO}_{3}$ for $6 \mathrm{~h}$ at $450^{\circ} \mathrm{C}$ and $500^{\circ} \mathrm{C}$, respectively. Bath is the equipment dedicated to chemical strengthening.

Hardness of bone china glaze was measured using micro Vickers hardness tester (Shimadzu, HMV 2T E, Japan). To check for residual stresses inside the glaze, both side surfaces of the specimen were subjected to mirror polishing after being processed to the thickness of $0.2 \mathrm{~mm}$ and residual stresses were measured using the strain meter (HanKookLab, HKL-HPASM-S200, Korea). For measurements of glass transition temperatures and thermal expansion coefficients, a dilatometer (Netzsch, Dilatometer 402C, Germany) was used. Status of presence of crystalline phases inside the glaze was checked through a polarizing microscope (Nikon, OPTIPHOT-POL, Japan) and a scanning electron microscope (Jeol, SEM-6701F, Japan). Microstructures of the interfacial layer were observed after etching in $5 \mathrm{vol} \%$ HF solution for 30 seconds. Penetration depths and concentrations of $\mathrm{K}^{+}$ions after chemical strengthening were checked by EDS (Energy Dispersive spectroscopy, Oxford, Aztec, UK).

\section{Results}

Figure 1 shows the change in the hardness of glaze according to firing conditions. Depending on the firing conditions of the glaze, its hardness increase by about $5 \%$ in comparison with as-received sample. To statistically ascertain the effects of additional firing, a significant difference in hardness with firing condition was predicted by a 2 -sample t-test ; 1) null hypothesis : there is no difference in the average value of hardness as a function of firing temperature conditions, 2) alternative hypothesis : the average value of hardness increases when firing temperature is higher and time is longer (confidence level : 95\%). The comparative analysis results between each conditions are shown in Table 3. The alternative hypothesis could be adopted as the $p$-value was within confidence level $(p<0.05)$

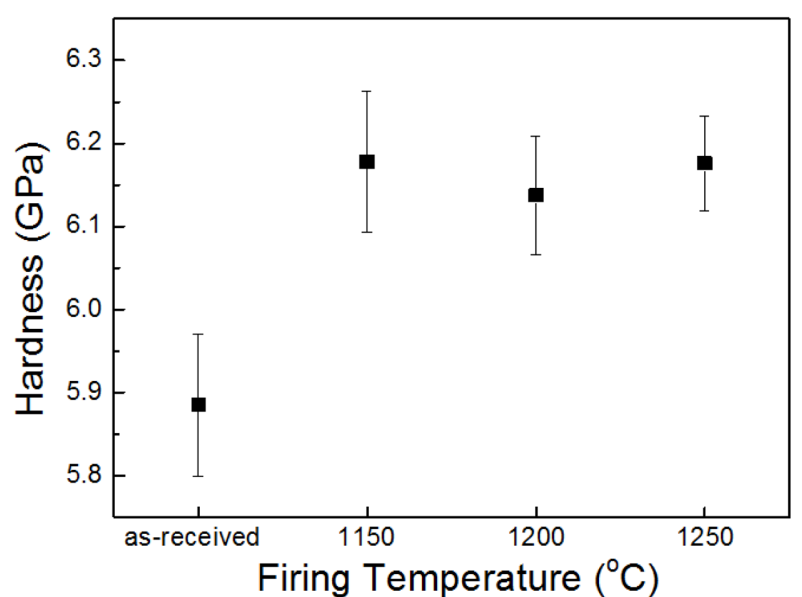

Fig. 1. Change in hardness as a function of firing conditions.

Table 3. $p$-Values of 2-sample t-Test Analysis as a function of Firing Conditions

\begin{tabular}{cccc}
\hline & $1150^{\circ} \mathrm{C} 60 \mathrm{~min}$ & $1200^{\circ} \mathrm{C} 60 \mathrm{~min}$ & $1250^{\circ} \mathrm{C} 60 \mathrm{~min}$ \\
\hline $\begin{array}{c}\text { As-received } \\
\left(1150^{\circ} \mathrm{C} \text { 30min. }\right)\end{array}$ & 0.021 & 0.026 & 0.011 \\
\hline $1150^{\circ} \mathrm{C} 60 \mathrm{~min}$. & - & 0.638 & 0.507 \\
\hline $1200^{\circ} \mathrm{C} 60 \mathrm{~min}$. & - & - & 0.342 \\
\hline
\end{tabular}

according to the test result. So, if firing temperature increased or time lengthened, it could be considered that the hardness of commercial products increased statistically by about $5 \%$ and commercial pottery production process has room for improvement.

Figure 2 shows the change in residual stresses as a function of firing condition. Reheat treated samples had a relatively high compressive strength as compared with asreceived sample. From such result, the hardness may be considered to have been increased as the change in firing temperatures produced compressive stresses inside the glaze. In the case of commercial products without additional heat treatment, it was difficult to measure the residual stress due to the small particles inside. They were estimated to remain unmelted New Zealand kaolin, which was 

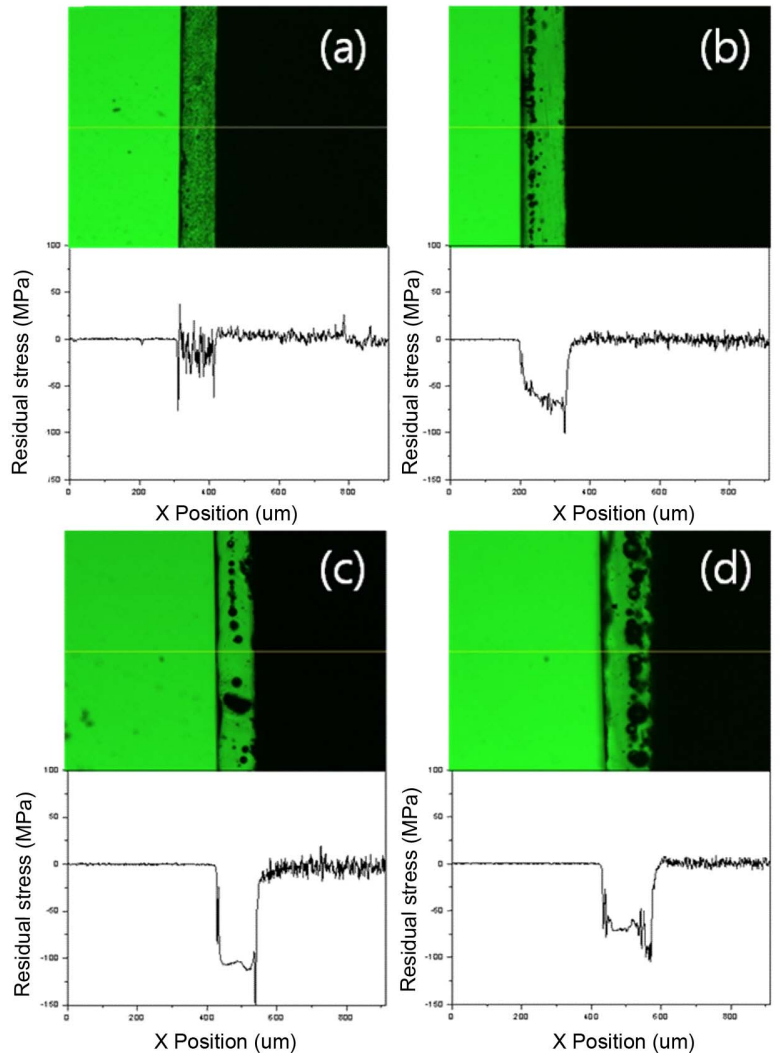

Fig. 2. Residual stresses as a function of firing condition ; (a) $1150^{\circ} \mathrm{C}-30 \mathrm{~min}$ (as-received), (b) $1150^{\circ} \mathrm{C}-60 \mathrm{~min}$, (c) $1200^{\circ} \mathrm{C}-60 \mathrm{~min}$. and (d) $1250^{\circ} \mathrm{C}-60 \mathrm{~min}$.

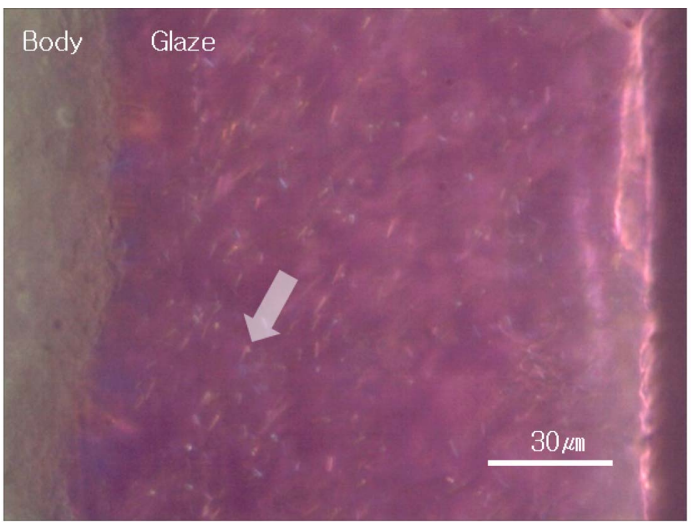

Fig. 3. Polarizing microscope image of as-received bone china $(\times 400)$.

used as an inorganic binder for frit glaze. Figure 3 shows small particles in a cross section of the glaze layer in commercial products using a polarizing microscope. Particles, indicated by an arrow in Fig. 3, are shown the polarization diffraction interference. Thus, they were thought to be the crystalline phases of several micrometers. Because the New Zealand kaolin composes of $50.4 \mathrm{wt} \%$ of silica and $35.5 \mathrm{wt} \%$ of alumina, a general commercial firing condition, $1150^{\circ} \mathrm{C}$ and 30 minutes, is reckoned not to react and melt Kaolin sufficiently together with frit. ${ }^{17)}$

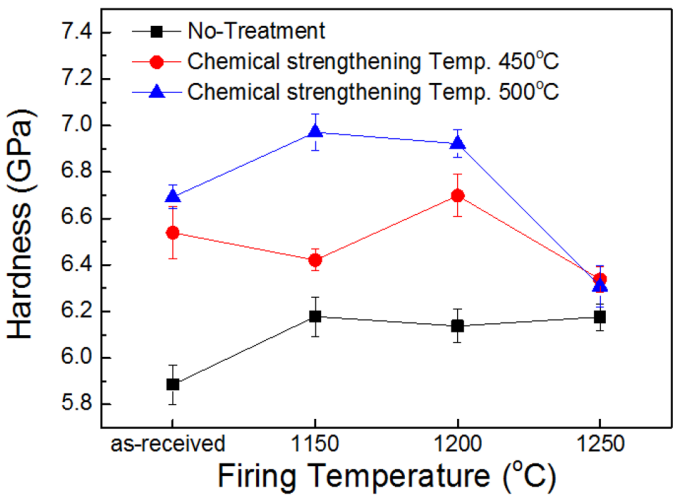

Fig. 4. Variation of hardness with firing conditions and ion exchange temperatures.

Figure 4 compares the change in hardness in accordance with firing and chemical strengthening conditions. As compared with as-received sample, there was about $13 \%$ of enhancement effect through chemical strengthening except for $1250^{\circ} \mathrm{C}$. Meanwhile, the higher effect of hardness enhancement was observed at a chemical strengthening temperature of $500^{\circ} \mathrm{C}$ compared with $450^{\circ} \mathrm{C}$. To identify this, the penetration depths for $\mathrm{K}^{+}$ions inside the glaze were checked through EDS line scan, which is shown in Fig. 5. Except for the specimens additionally fired at $1250^{\circ} \mathrm{C}$, the strengthening depths of about $10 \mu \mathrm{m}$ at $500^{\circ} \mathrm{C}$, and of $5 \mu \mathrm{m}$ at $450^{\circ} \mathrm{C}$ were observed.

\section{Discussion}

As shown in Fig. 1, when as-received samples were reheated at the same or higher temperature, improvement in hardness can be affirmed to the extent that a statistically significant difference occurred. According to Goodier's theory recited by Kingery, residual stresses are produced in the glaze layer as shown in the Eq. (1). ${ }^{18)}$

$$
\sigma_{g l}=E\left(\mathrm{~T}_{0}-\mathrm{T}_{1}\right)\left(\alpha_{g 1}-\alpha_{\mathrm{b}}\right)(1-j)\left(1-3 j+6 j^{2}\right)
$$

where, $\sigma_{\mathrm{gl}}$ is the stress in the glaze on an infinite slab, $\mathrm{T}_{0}$ the temperature when there is no stress in the glaze, $\mathrm{T}_{1}$ new temperature, $\mathrm{E}$ the elastic modulus of the glaze, $\mathrm{a}_{\mathrm{gl}}$ the CTE of the glaze, $a_{b}$ the CTE of the ceramic body, and $j$ is the thickness of the glaze/the thickness of the body.

Since the thickness ratio(j) for the glaze layer and the body has a very small value, the $\mathrm{j}$ value is practically negligible, simplifying the Eq. (1) to the Eq. (2).

$$
\sigma_{g l}=E\left(\mathrm{~T}_{0}-\mathrm{T}_{1}\right)\left(\alpha_{\mathrm{gl}}-\alpha_{\mathrm{b}}\right)
$$

The CTE of glaze is smaller than body minutely and the difference is $0.32 \times 10^{-6} /{ }^{\circ} \mathrm{C}$. The estimable compressive stress inside the glaze is $12 \mathrm{MPa}$ in the calculation according to Eq. (2). It has a very large difference from the value measured by the strain meter of $80 \sim 110 \mathrm{MPa}$. To generate 


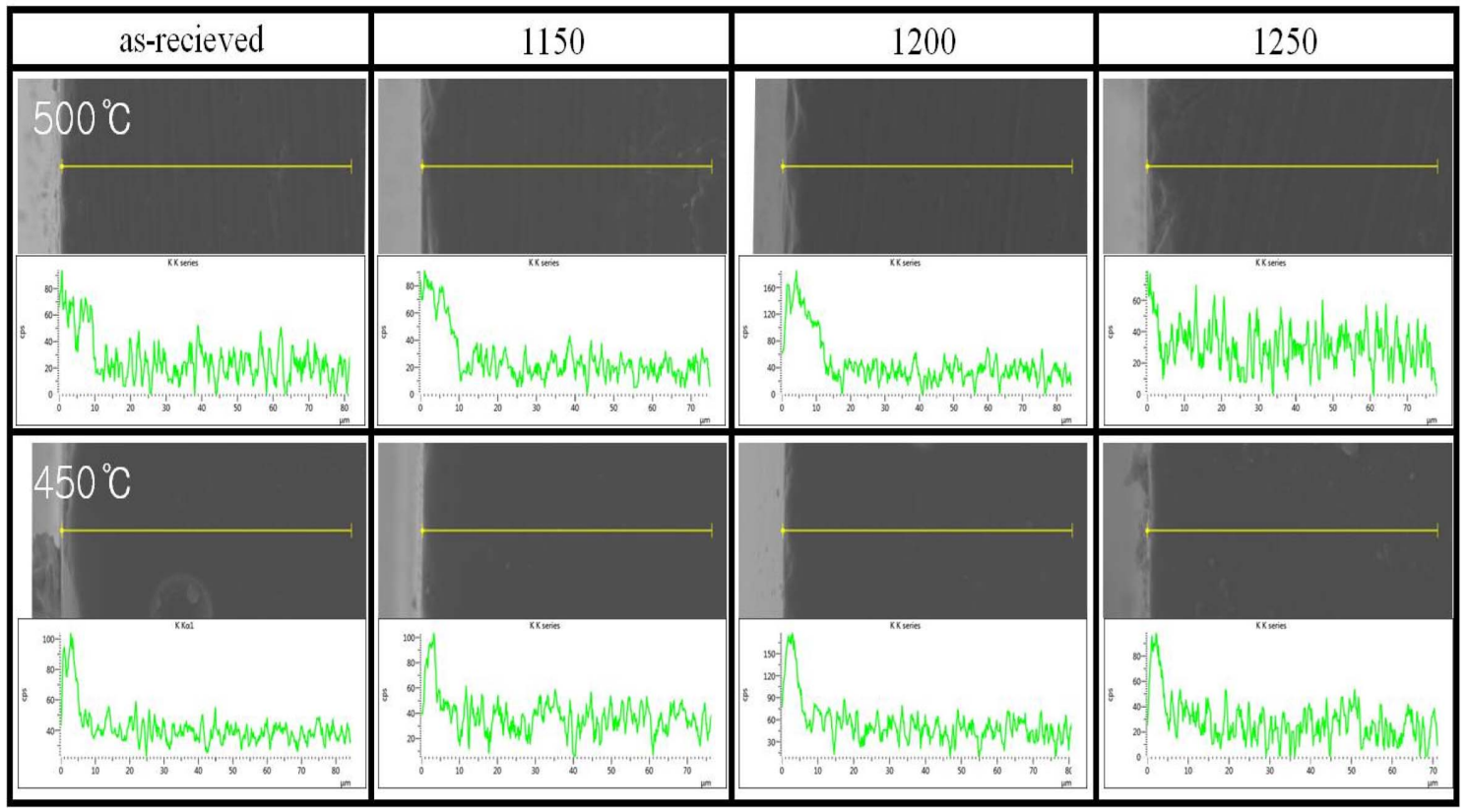

Fig. 5. Depth profile of potassium as a function of firing conditions after chemical strengthening at 450 and $500^{\circ} \mathrm{C}$.

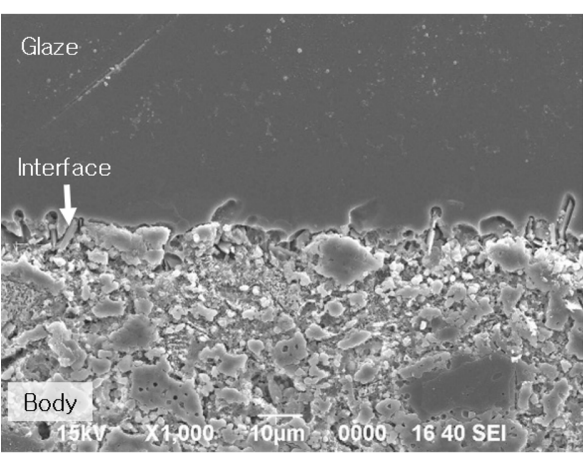

(a)

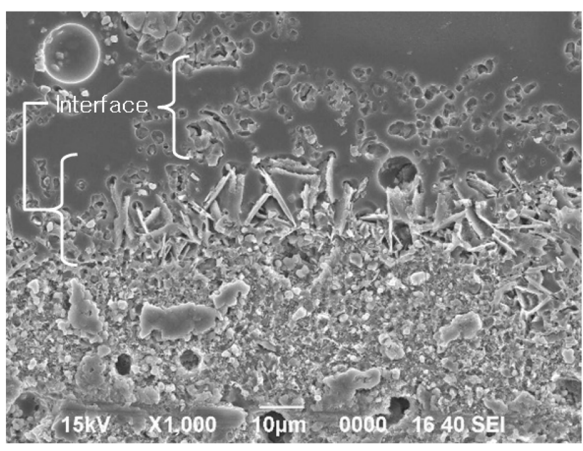

(c)

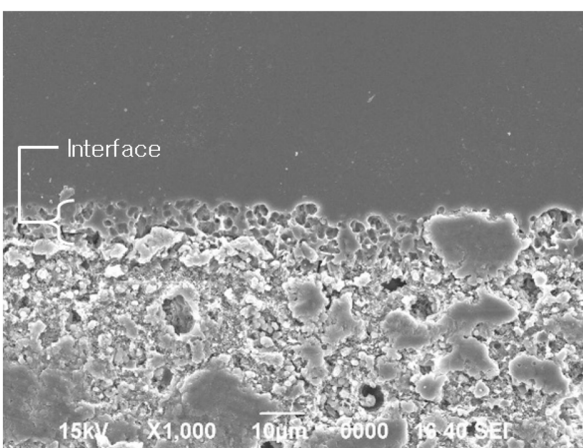

(b)

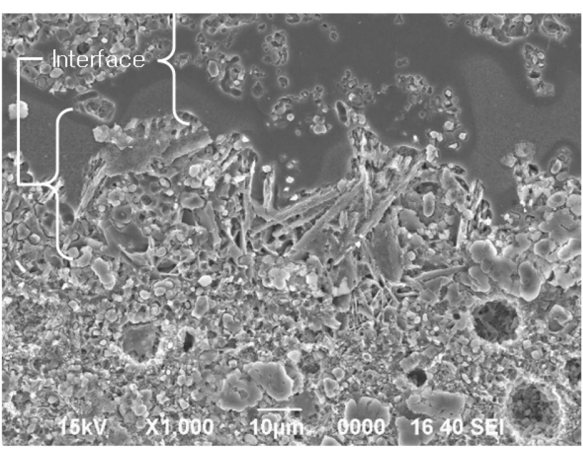

(d)

Fig. 6. SEM images of interface as a function of firing conditions (a) $1150^{\circ} \mathrm{C}-30 \mathrm{~min}$ (as-received), (b) $1150^{\circ} \mathrm{C}-60 \mathrm{~min},(\mathrm{c}) 1200^{\circ} \mathrm{C}-$ $60 \mathrm{~min}$. and (d) $1250^{\circ} \mathrm{C}-60 \mathrm{~min}$.

more than the measured compressive strength of $80 \mathrm{MPa}$ in glaze, there should be a difference between CTEs of glaze and body by more than $2 \times 10^{-6} /{ }^{\circ} \mathrm{C}$, theoretically. Kara et al have shown that a reaction layer is developed between the body and the glaze during heat treatment process and diffusion occurs from the body to the glaze or from the glaze to the body. ${ }^{12,19)}$ In the present study, the similar reaction layer was also observed distinctly with an increase in the firing temperatures, which is shown in Fig. 6. Ichiko has presumed that such reaction layer has about an intermediate value of CTEs between the glaze and the body, reducing internal residual stresses. ${ }^{20)}$ We has also studied the rela- 


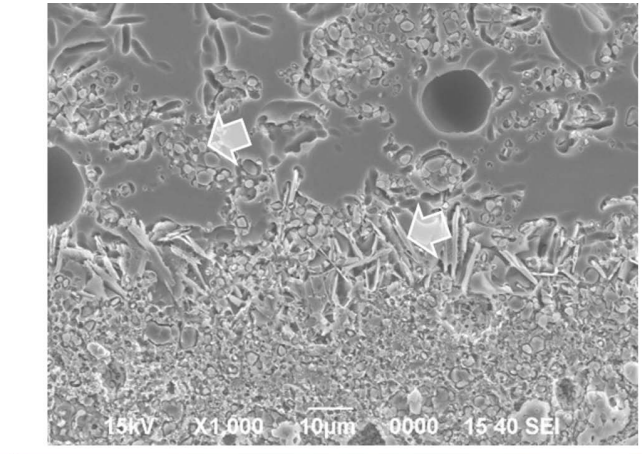

(a)

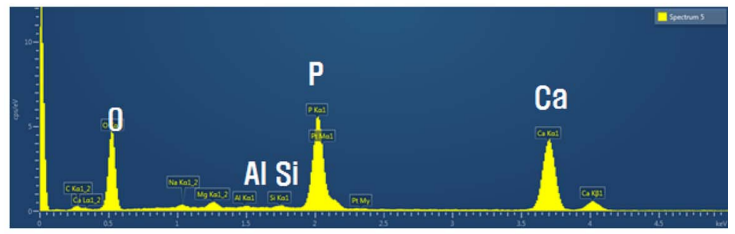

(b)

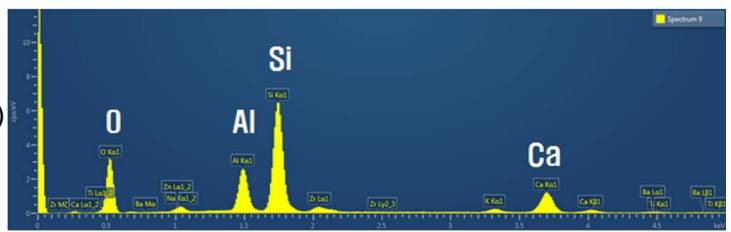

Fig. 7. EDS Analysis of two types of particles in interface layer of the specimens fired at $1200^{\circ} \mathrm{C}$ for $60 \mathrm{~min}$. (a) round (b) needle-like.

tionship between reaction layer and residual stress, obtaining the results that a compressive stress higher than $50 \mathrm{MPa}$ could be produced in the glaze layer when the reaction layer had a thickness larger than $30 \mu \mathrm{m}$ with a CTE of $14 \times 10^{-6} /{ }^{\circ} \mathrm{C}$ which was higher than that of the body or the glaze. ${ }^{21)}$ Fig. 7 shows a cross section of the glaze layer fired at $1200^{\circ} \mathrm{C}$, where the round particles had calcium and phosphorus as the main component while the needle-shaped ones were affirmed to be an oxide consisting of calcium, aluminum and silicon as the main components. Kara et al found that the needle-shaped crystals were Anorthite, the round particles a calcium phosphate-based phase, presumably hydroxyapatite (HAp) or 8-tricalcium phosphate (TCP). Both HAp and TCP are the materials with a CTE higher than $10 \times 10^{-6} /{ }^{\circ} \mathrm{C}$ and considered as the major cause for formation of residual stresses in the glaze; the CTE of HAp is $13.59 \times 10^{-6} /{ }^{\circ} \mathrm{C},{ }^{22)}$ and the CTE of TCP $12 \times 10^{-6} /{ }^{\circ} \mathrm{C}$. ${ }^{23)}$ Therefore, the compressive stress formed in bone china glaze is not caused by the difference in CTE between the glaze and the body, but may be believed to be formed by the differences in CTEs between the reaction layer and the glaze as well as between the glaze and the body.

Meanwhile, the fact that the enhancement effect of hardness is greater at $500^{\circ} \mathrm{C}$ than at $450^{\circ} \mathrm{C}$ upon chemical strengthening is considered to be caused by the compressive stress inside the glaze before chemical strengthening. Varshneya has studied that the driving force for ions to penetrate into the glass is reduced when compressive stresses

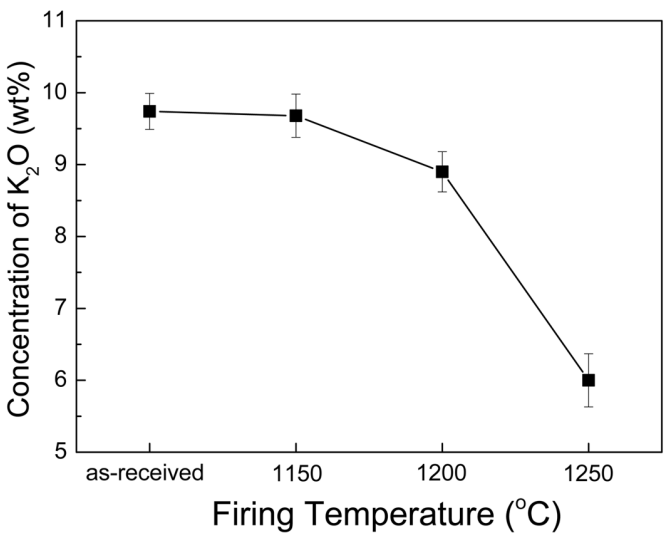

Fig. 8. Change of potassium concentration of surface as a function of firing conditions after ion exchange at $500^{\circ} \mathrm{C}$ for $6 \mathrm{~h}$.

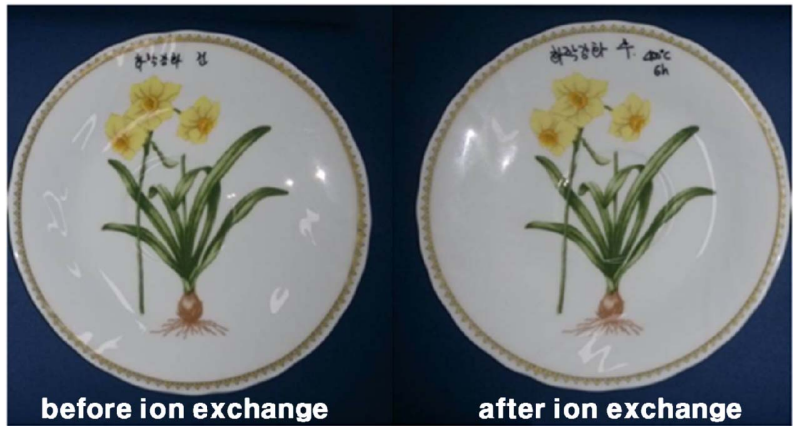

Fig. 9. Changes in the color of the transfer paper before and after chemical strengthening.

exist inside the glaze before chemical strengthening process. ${ }^{24)}$ Because a large amount of compressive stress was produced inside the glaze after additional heat treatment, the diffusion of the ions became difficult as claimed by Varshneya. So, the chemical strengthening temperature needs to be higher for $\mathrm{K}^{+}$ions to diffuse into the glaze.

In the case of specimens heat treated at $1250^{\circ} \mathrm{C}$, the effect of hardness enhancement was relatively low even after chemical strengthening. Kucuk et al, reported that alkali ions in glass are volatilized slowly above $1050^{\circ} \mathrm{C}$ and are accelerated above $1300^{\circ} \mathrm{C} .{ }^{25)}$ So, it was presumed that the firing at $1250^{\circ} \mathrm{C}$ induces a decrease in the amount of $\mathrm{Na}^{+}$ ions on the glaze surface and chemical strengthening effect is reduced because the ion-exchange depends on inter-diffusion according to the concentration gradients of $\mathrm{Na}$ and $\mathrm{K}$ ions. The amounts of potassium on the glaze surface after reheat treatment and chemical strengthening is shown in Fig. 8. Relatively small potassium amounts of were detected in the case of firing at $1250^{\circ} \mathrm{C}$ than at other temperatures.

Lastly, the side effect, whether chemical strengthening affects the color of transfer papers decorating commercial products, was checked. As shown in Fig. 9, the decorating colors was not changed at all after chemical strengthening, so this process is expected to be applied to bone china for improving it glaze surface hardness. 


\section{Conclusions}

To improve hardness of the glaze layer in bone china as the pronoun for luxury tableware, the status of glaze was inspected and either the firing conditions were changed or the chemical strengthening process was additionally applied.

In the case of commercial products, kaolin as an inorganic binder could not sufficiently react with frit and the glaze could be completely vitrified. When more than 30 minutes of time at the firing temperature of $1150^{\circ} \mathrm{C}$ was added or the temperature was raised slightly higher, the hardness of the glaze increased by about $5 \%$. It was attributed to form the interface layer which have higher $\mathrm{CTE}$ than $10 \times 10^{-6} /{ }^{\circ} \mathrm{C}$ between the glaze and the body. When chemical strengthening at $500^{\circ} \mathrm{C}$ was applied to bone china with heat treatment, the glaze hardness enhanced by about $18 \%$ as compared with commercial products. The compressive stress layer formed on the glaze surfaces more than $10 \mu \mathrm{m}$ due to interdiffusion between $\mathrm{Na}^{+}$ions in the glaze and $\mathrm{K}^{+}$ions in the molten bath of $\mathrm{KNO}_{3}$.

As a conclusion, enhancement of the resistance to living scratches can be expected for bone china products through an increase in the surface compressive stresses in the glaze layer when the glaze of bone china is sufficiently vitrified below $1200^{\circ} \mathrm{C}$ and chemical strengthening at $500^{\circ} \mathrm{C}$ is applied to bone china.

\section{REFERENCES}

1. W. R. H. Ramsay, K. Sutton, and E. G. Ramsay, "Bow Porcelain: Glaze Compositions Associated with the Phosphatic Ware 1742.1774," Proc. R. Soc. Victoria, 123 [2] 161-71 (2004).

2. S. A. F. Batista, P. F. Messer, and R. J. Hand, "Fracture Toughness of Bone China and Hard Porcelain," Br. Ceram. Trans., 10 [6] 256-59 (2001).

3. S. R. Braganca, C. P. Bergmannm, and H. Hubner, "Effect of Quartz Particle Size on the Strength of Triaxial Porcelain,” J. Eur. Ceram. Soc., 26 [16] 3761-68 (2006).

4. G. Stathis, A. Ekonomakou, C. J. Stournaras, and C. Ftikos, "Effect of Firing Conditions, Filler Grain Size and Quartz Content on Bending Strength and Physical Properties of Sanitary Ware Porcelain," J. Eur. Ceram. Soc., 24 [8] 2357-66 (2004).

5. A. D. N. Junior, D. Hotza, V. C. Soler, and E. S. Vilches, "Analysis of The Development of Microscopic Residual Stresses Particles in Porcelain Tile," J. Eur. Ceram. Soc., 28 [14] 2629-37 (2008).

6. X. Cheng, S. Ke, Q. Wang, H. Wang, A. Shui, and P. Liu, "Characterization of Transparent Glaze for Single-Crystalline Anorthite Porcelain," Ceram. Int., 38 [6] 4901-8 (2012).

7. D. U. Tulyaganov, S. Agathopoulos, H. R. Fernandes, and J. M. F. Ferreira, "The Influence of Incorporation of $\mathrm{ZnO}$ Containing Glazes on the Properties of Hard Porcelains," J. Eur. Ceram. Soc., 27 [2-3] 1665-70 (2007).

8. C. B. Ustundag, Y. K. Tur, and A. Capoglu, "Mechanical
Behavior of A Low-Clay Translucent White Ware," J. Eur. Ceram. Soc., 26 [1-2] 169-77 (2006).

9. E. D. Spinosa and K. J. Davies, Lead-Free Glaze or Enamel For Use On Ceramic Bodies, US 5447891 A (1993).

10. Y. Tokunaga, Lead-free Frit Glaze, US 5362687 A (1992).

11. R. O. Knapp, "Low-Temperature Lead-Free Glaze for Alumina Ceramics"; US Patent 5,677,250 (October 17, 1994).

12. A. Kara and R. Stevens, "Interactions between an ABS Type Leadless Glaze And a Biscuit Fired Bone China Body During Glost Firing. Part II: Investigation of Interactions," J. Eur. Ceram. Soc., 22 [7] 1103-12 (2002).

13. V. Rosa, H. N. Yoshimura, M. M. Pinto, C. Fredericci, and P. F. Cesar, "Effect of Ion Exchange on Strength and Slow Crack Growth of a Dental Porcelain," Den. Mater., 25 [6] 736-43 (2009).

14. K. J. Anusavice, C. Shen, and R. B. Lee, "Strengthening of Feldspathic Porcelain by Ion Exchange and Tempering," $J$. Dent. Res., 71 [5] 1134-38 (1992).

15. D. H. Kim, J. H. Maeng, Y. S. Han, H. T. Kim, S. C. Choi, and H. J. Kim, "The Mechanical Properties of Porcelain with Thermally and Chemically Induced Residual Stress on Glaze," J. Korean Ceram. Soc., 51 [5] 487-91 (2014).

16. E. Cooper, D. Royle, Glaze for Potter, pp.104, Charles Scribner's sons, New York, 1978.

17. A. Kara and R. Stevens, "Interactions between an ABS Type Leadless Glaze and a Biscuit Fired Bone China Body During Glost Firing. Part I : Preparation of Experimental Phases," J. Eur. Ceram. Soc., 22 [7] 1095-102 (2002).

18. W. D. Kingery, "Factors Affecting Thermal Stress Resistance of Ceramic Materials," J. Am. Ceram. Soc., 28 [1] 315 (1955)

19. A. Kara and R. Stevens, "Interactions Between a Leadless Glaze and a Biscuit Fired Bone China Body During Glost Firing. Part III: Effect of Glassy Matrix Phase," J. Eur. Ceram. Soc., 23 [10] 1617-82 (2003).

20. T. Ichiko, "A Consideration about the Glazing to the Bone China (in Japanese)," J. Ceram. Soc. Jpn., 102 [5] 471-75 (1994).

21. H. J. Kim, D. H. Kim, D. M. Kim, J. H. Choi, Y. S. Han, S. M. Lee, and H. T. Kim, "The Generation of the Residual Stress in ABS Type Glaze of Commercial Bone China," J. Eur. Ceram. Soc., in press.

22. S. Reddy, A. K. Dubey, B. Basu, R. Guo, and A. S. Bhall, "Thermal Expansion Behavior of Biocompatible Hydroxyapatite-BaTiO3 Composites for Bone Substitutes," Integrated Ferroelectrics, 131 [1] 147-52 (2011).

23. A. Capoglu, "Elimination of Discolouration in Reformulated Bone China Bodies," J. Euro. Ceram. Soc., 25 3157-64 (2005).

24. A. K. Varshneya and G. A. Dumais, "Influence of Externally Applied Stresses on Kinetics of Ion Exchange in Glass," J. Am. Ceram. Soc., 68 [7] C165-66 (1985).

25. A. Kucuk, A. G. Clare, and L. E. Jones, "Differences Between Surface and Bulk Properties of Glass Melts I. Compositional Differences and Influence of Volatilization on Composition and Other Physical Properties," J. NonCryst. Solids, 261 [1-3] 28-38 (2000). 